Article

\title{
Mechanical and Heterogeneous Properties of Coal and Rock Quantified and Mapped at the Microscale
}

\author{
Changlun Sun ${ }^{1,2} \mathbb{D}$, Guichen $\mathrm{Li}^{1,2, *}$, Suhui Zhang ${ }^{1,2}$, Jiahui $\mathrm{Xu}^{1,2}$ and Houqiang Yang ${ }^{1,2}$ \\ 1 Key Laboratory of Deep Coal Resource Mining, Ministry of Education of China, China University of Mining \\ and Technology, Xuzhou 221116, China; TS16020043A3@cumt.edu.cn (C.S.); \\ TS17020011A3@cumt.edu.cn (S.Z.); TS19020060A31LD@cumt.edu.cn (J.X.); yhq@cumt.edu.cn (H.Y.) \\ 2 School of Mines, China University of Mining and Technology, Xuzhou 221116, China \\ * Correspondence: Liguichen@cumt.edu.cn; Tel.: +86-158-0521-5566
}

Received: 11 December 2019; Accepted: 30 December 2019; Published: 2 January 2020

\begin{abstract}
Due to the impossibility of obtaining intact standard experimental samples, it is difficult to test the mechanical properties of soft and broken coal and rock obtained from deep coal mines. So, an advanced experimental technology based on a small sample volume, nanoindentation technology, was introduced and used to measure the mechanical parameters of them. By using the averaging method, the hardness of shale, mudstone and coal are $1191.90 \mathrm{MPa}, 674.95 \mathrm{MPa}$ and $424.30 \mathrm{MPa}$, respectively; their elastic moduli are $20.39 \mathrm{GPa}, 11.72 \mathrm{GPa}$ and $5.47 \mathrm{GPa}$; and their fracture toughness were $1.66 \mathrm{MPa} \cdot \mathrm{m}^{0.5}, 1.28 \mathrm{MPa} \cdot \mathrm{m}^{0.5}$ and $0.77 \mathrm{MPa} \cdot \mathrm{m}^{0.5}$. These three mechanical parameters were used to quantify and map the heterogeneous properties of coal and rock for convenience and accuracy. For example, the inter quartile range (IQR) of the hardness of shale, mudstone, and coal are 1502.10 MPa, 1016.20 MPa and 54.64 MPa, respectively, meaning that coal has the best homogeneity among them. Nanoindentation technology provides researchers with a convenient method to conduct mechanical experiments at the microscale.
\end{abstract}

Keywords: broken coal and rock; nanoindentation; mechanical properties; heterogeneous properties; microscale

\section{Introduction}

The mechanical properties of coal and rock are of key importance in coal mining and exploration [1-3], rock strata control [4-6], hydraulic fracturing [7-9], rock burst [10,11], (enhanced) coal bed methane recovery (CBM/ECBM) [12], water hazard control [13,14], geo-sequestration [15,16], and underground coal gasification in coal mines and deep unmineable coal seams [17].

Traditionally, the mechanical properties of intact coal and rock were mainly measured by standard centimeter-scale tests, mainly including uniaxial compression, triaxial compression, tension, bending, cutting, and polyaxial tests [18-22]. However, for soft and broken coal and rock obtained from deep underground coal mines, this experimental method is not feasible due to the impossibility of obtaining intact standard samples. As a result, it is necessary to find an innovative and advanced technique, which only requires a small sample volume, to measure geo-mechanical properties of coal and rock in coal mines.

In this study, to measure the mechanical parameters of soft and broken coal and rock, firstly, nanoindentation technique was briefly introduced, including its calculation method and experimental procedures. Secondly, mechanical parameters were calculated by averaging method. Thirdly, the heterogeneous properties of coal and rock were also quantified and mapped by using their mechanical parameters. This study provides a new technique to obtain the mechanical properties of geomaterials at the microscale. 


\section{Materials}

East China, one of the most important coal mining areas, is facing the challenge of deep mining. For some mines, soft and broken coal and rock have negatively affected the stability of gateways. In this context, mechanical properties are becoming more and more important for researchers and engineers in the field of coal mining. For soft-rock gateways, such as the 313 haulage gateway in Qinan coal mine in Anhui Province (geographic coordinates of $33^{\circ} 44^{\prime} 12^{\prime \prime} \mathrm{N}, 117^{\circ} 03^{\prime} 47^{\prime \prime} \mathrm{E}$ ) and $-690 \mathrm{~m}$ main gateway in Donghuantuo coal mine in Hebei Province (geographic coordinates of $39^{\circ} 38^{\prime} 41.49^{\prime \prime} \mathrm{N}, 118^{\circ} 0^{\prime} 11.14^{\prime \prime} \mathrm{E}$ ) (Figure 1), their stability and lifetime are heavily dependent on the mechanical properties of the surrounding rock, such as coal and soft rock. These soft-rock gateways are inclined to collapse during a service period, posing life risks to workers and restricting high production [23].

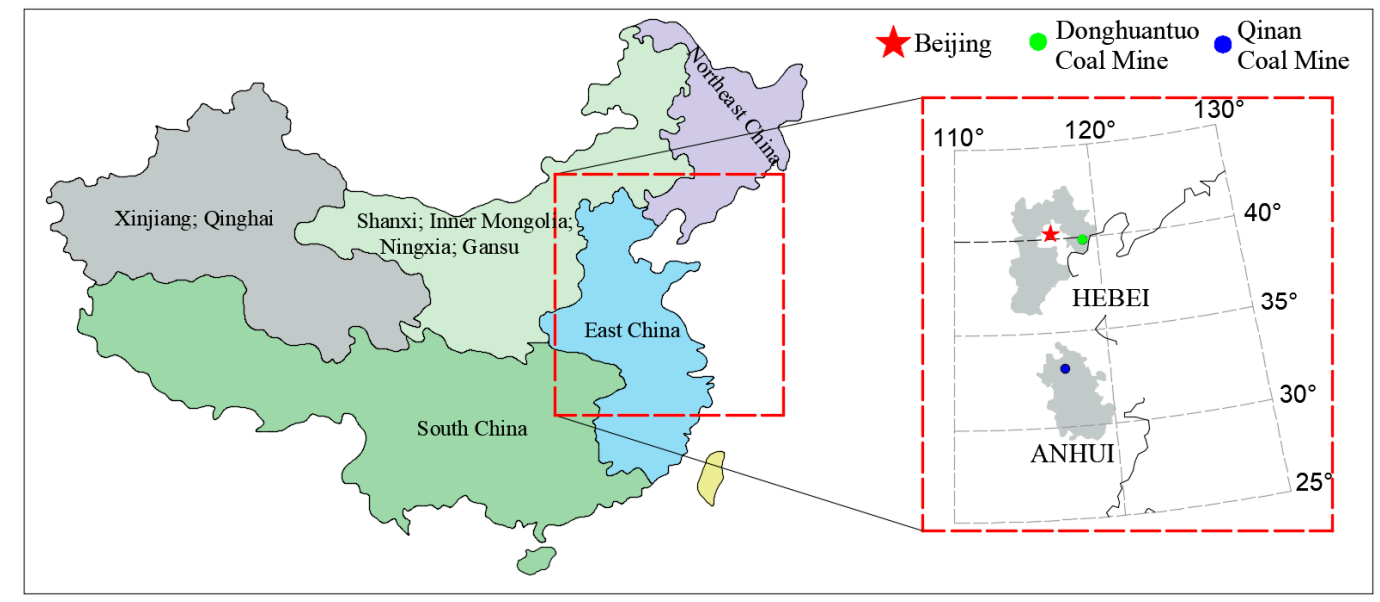

Figure 1. Two studied coal mines in East China.

Traditionally, to clearly understand the mechanical properties of coal and rock surrounding the gateway, it is common to obtain coal and rock blocks and process them into inch-sized samples in laboratory. To quantify the mechanical parameters of soft and broken coal and rock, in Figure 2, (a) Sample \#1 (shale) and (c) Sample \#3 (coal) were collected from the sidewall and roof of the 313 haulage gateway in the Qinan Mine Company, and (b) Sample \#2 (mudstone) was obtained from the roof of $-690 \mathrm{~m}$ main gateway in the Donghuantuo Mine Company. According to Figure 2, these samples are broken up, and it is impossible to obtain macroscale standard samples to conduct inch-size experiments, which hinders the successful conduction of conventional rock mechanical testing.
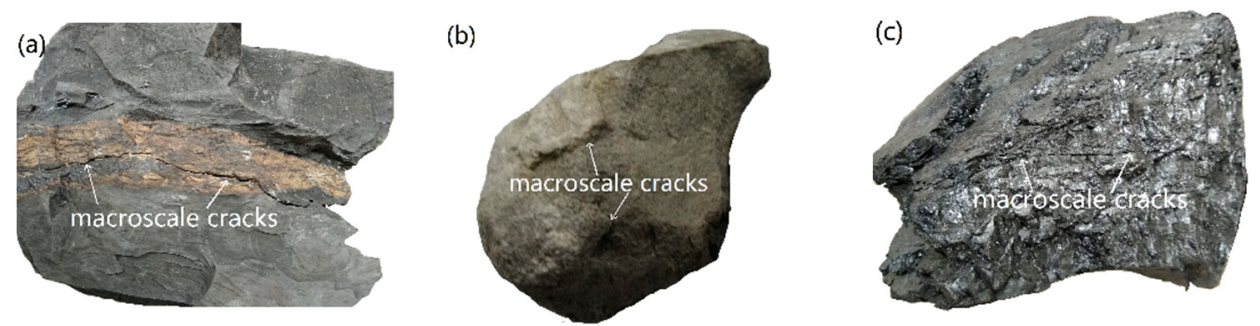

Figure 2. Photos of (a) Sample \#1, (b) Sample \#2 and (c) Sample \#3.

\section{Experimental Method}

\subsection{Concept of Nanoindentation}

Nanoindentation, also called depth sensing technique, was firstly developed by Kalei in 1968 and provides a unique method to obtain the mechanical parameters of materials with very small 
volumes [24,25]. It is a technique whereby an indenter tip of known geometry and mechanical properties is used to make an impression in a sample whose mechanical properties are unknown.

After that, researchers found a method to explain the data from tests, and this technique developed rapidly and was applied for estimation of the mechanical properties of various materials [26]. The procedure proposed by Oliver and Pharr $[27,28]$ can be used to deduce the hardness and elastic moduli of various materials, and other indentation-based procedures have been proposed to investigate other mechanical parameters, such as fracture toughness [29,30], fatigue and impact testing [31]. Nowadays, nanoindentation technique is a very powerful method to investigate the mechanical properties of biomaterials [32,33], metals [34], ceramics [35], polymers, and composites [36].

In the realm of geotechnical engineering, Zhu et al. applied this technique to map the micromechanical properties of natural shale [37]. Alstadt et al. analysed the microscale morphology of kerogen and the micromechanical properties of green river oil shale in both the bedding plane normal and bedding plane parallel directions [38]. Mashhadian and Abedi studied the effect of mineralogy on mechanical properties of shale $[39,40]$. Bobko et al. used the nanoindentation method in shale studying, and found the link between mineral compositions and mechanical properties [41,42]. Delafargue and Gathier studied shale mechanical properties in multiscale, and homogenized their micro strength to derive that in macroscale, which is one of the most important research directions in geotechnical engineering $[43,44]$. Kossovich and Zhang adopted the nanoindentation technique to investigate the mechanical properties of coal $[45,46]$. All above studies laid a solid foundation for the application and proliferation of this technique in mining engineering, to measure the mechanical properties of soft and broken coal and rock.

\subsection{Calculation of Mechanical Parameters}

After experimental testing, nanoindentation devices can record a whole set of load-depth (displacement) data (Figure 3a). At the same time, indents matching the indenter shape can be found on the surface of materials, as shown in Figure $3 b$.

(a)

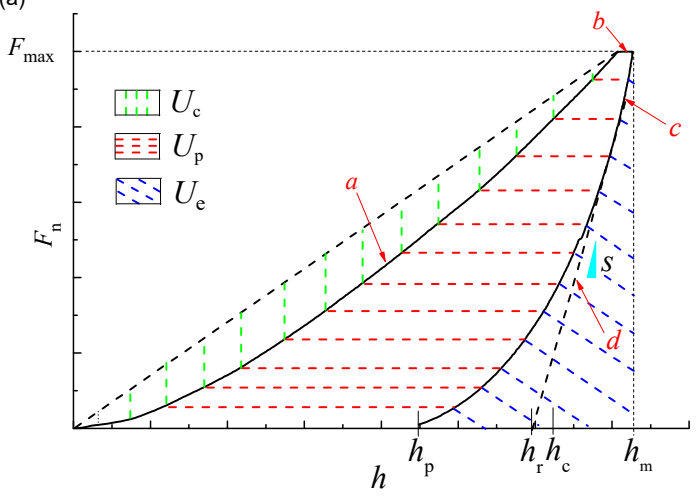

(b)

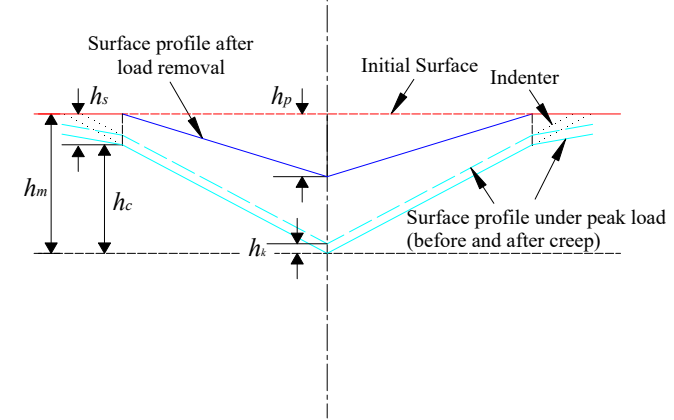

Figure 3. (a) Load-depth curve and (b) indent profile of the Berkovich indenter.

Figure 3a shows typical indentation curve, which consists of three stages of loading (a), holding (b), and unloading $(\mathrm{c})$, where $F_{n}$ is the load $(\mathrm{mN}) ; h$ is the depth $(\mathrm{nm}) ; U_{c}$ is the fracture energy $(\mathrm{mN} \cdot \mathrm{nm})$; $U_{p}$ is the plastic energy $(\mathrm{mN} \cdot \mathrm{nm}) ; U_{e}$ is the elastic energy recovered during unloading (uN.nm); $S$ is the stiffness $(\mathrm{mN} / \mathrm{nm}) ; h_{m}$ is the maximum depth $(\mathrm{nm}) ; h_{p}$ is the residual depth after the unloading process $(\mathrm{nm}) ; h_{r}$ is the depth of the tangent line (nm); and $h_{c}$ is the effective contact depth (nm) that is defined as the actual depth of the indenter in contact with the cavity of the sample under the maximum load, as Figure $3 \mathrm{~b}$ illustrates. $h_{s}$ is sinking depth $(\mathrm{nm})$ and $h_{k}$ is creep deformation $(\mathrm{nm})$ in Figure $3 \mathrm{~b}$.

The load applied rises with the displacement increase at the loading stage. This stage can be regarded as the combination of elastic and plastic deformation; whereas during the unloading stage, only elastic deformation can be recovered, and this can be used to calculate the mechanical properties of 
materials. It is worth noting that due to the existence of the holding load stage (creep stage), the indent profile of the Berkovich indenter consists of two surface profiles before and after creep. The results of a load-depth curve can be analyzed to obtain material mechanical parameters, such as hardness $\left(H_{I T}\right)$, elastic modulus $\left(E_{I T}\right)$, and fracture toughness $\left(K_{c}\right)$.

\subsubsection{Oliver and Pharr Method}

The classic data-interpreting model named the Oliver and Pharr method (hereinafter referred to as OP method), after Oliver and Pharr, is widely used at present to calculate hardness and elastic moduli $[27,28]$. In 1961, Stillwell and Tabor proposed the reduced moduli [47], and this can be used to calculate the elastic moduli of materials by

$$
\frac{1-v_{I T}^{2}}{E_{I T}}=\frac{1}{E_{r}}-\frac{1-v_{i}^{2}}{E_{i}}
$$

where $E_{I T}$ and $v_{I T}$ are elastic modulus and Poisson's ratio of materials, $v_{I T}=0.3$ in this study, which has a very little effect on the calculation results; $E_{i}$ and $v_{i}$ are the same parameters for a diamond indenter, $E_{i}=1141 \mathrm{GPa}$ and $v_{i}=0.07$, and the effects of rigid indenters on the measurement of elastic modulus can be ignored.

Then, according to the theory proposed by Doerner [26] and King [48], the hardness $\left(H_{I T}\right)$ and reduced modulus $\left(E_{r}\right)$ can be calculated through the following two equations:

$$
H_{I T}=\frac{F_{\max }}{A_{c}}
$$

and

$$
E_{r}=\frac{S \sqrt{\pi}}{2 \beta \sqrt{A_{c}}}
$$

where $A_{c}$ is the projected contact area; $\beta$ is a constant ( $\beta=1.034$ for the Berkovich indenter) $[27,28]$.

Contact stiffness can be calculated by the tangent slope of the initial segment of the unloading curve, since some researchers thought this segment is linear [26]. However, Sneddon has used an exponential relationship to describe the unloading curve [49], which was confirmed by Oliver and Pharr. As a result, the unloading curve can be described by a simple power relation,

$$
F_{n}=\alpha\left(h-h_{p}\right)^{m}
$$

and the initial unloading slope representing the contact stiffness is calculated easily by analytically differentiating this expression at the peak load or the largest displacement:

$$
S=\left(\frac{d F_{n}}{d h}\right)_{h=h_{\max }}=\alpha m\left(h_{\max }-h_{p}\right)^{m-1},
$$

where $\alpha$ and $m$ are the power law fitting constants that can be determined by fitting procedure.

The projected contact area $\left(A_{c}\right)$ can be determined by the effective contact depth $\left(h_{c}\right)$ and the shape of the indenter, according to OP method. The effective contact depth and the projected contact area can be calculated by Equations (6) and (7), respectively.

$$
\begin{gathered}
h_{c}=h_{m}-\varepsilon\left(h_{m}-h_{r}\right) \\
A_{c}=24.5 h_{c}^{2},
\end{gathered}
$$

where $\varepsilon$ is constant about the shape of indenter, $\varepsilon=0.75$ for Berkovich indenter [27]. 


\subsubsection{Fracture Energy Method}

According to Figure 3a, for the curve, the relationship between total energy $\left(U_{t}\right)$, fracture energy $\left(U_{c}\right)$, recoverable plastic energy $\left(U_{p}\right)$, and unrecoverable elastic energy $\left(U_{e}\right)$ can be written as

$$
U_{t}=U_{c}+U_{e}+U_{P}
$$

and the total energy and critical energy release rate $\left(G_{c}\right)$ can be calculated by Equations (9) and (10).

$$
\begin{gathered}
U_{t}=\int_{0}^{h_{\max }} F_{n} d h_{c}=\frac{F_{\max }\left(h_{\max }+h_{k}\right)}{2} \text { and } \\
G_{c}=\frac{\partial U_{c}}{\partial A_{c}}=\frac{U_{c}}{A_{\max }},
\end{gathered}
$$

where $A_{\max }=24.5 h_{\max }^{2}$. The fracture toughness of coal and rock can be calculated by

$$
K_{c}=\sqrt{G_{c} E_{r}}
$$

\subsection{Experimental Procedures}

The preparation of samples was mainly based on available protocols $(I S O 14577,2015)$ and the work of Liu et al. [50,51], but we made some improvements in the polishing process to ensure the smoothness of surface. Three samples (shown in Figure 2) were broken into small pieces to make the testing surfaces parallel to the bedding plane. Then, they were put into resin liquid for $24 \mathrm{~h}$ under vacuum conditions to ensure that the resin provides enough mechanical support for the samples while being probed. After that, the surface was polished using different grits of sandpaper (from 800 to 3000 grit) and finished by diamond polishers to fit the surface roughness requirement for nanoindentation. The grain sizes of the diamond polishers were $3 \mu \mathrm{m}, 1 \mu \mathrm{m}$, and $50 \mathrm{~nm}$. Figure 4 represents the prepared samples for the experimental testing.

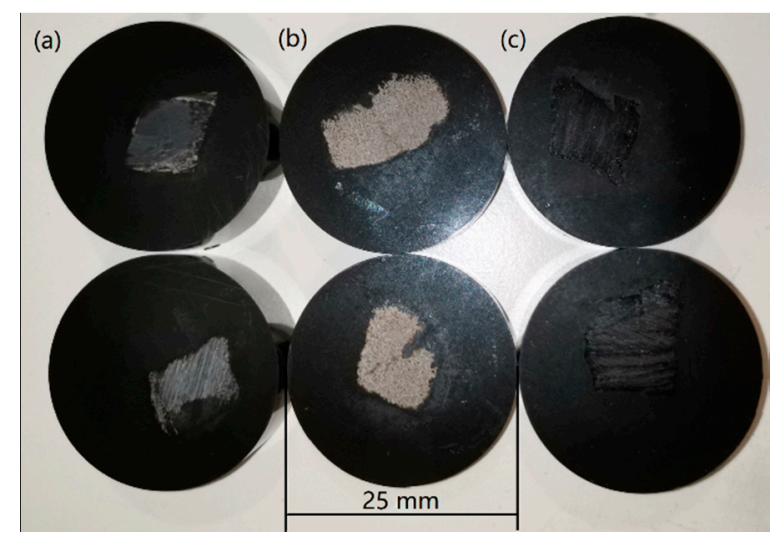

Figure 4. Prepared samples of (a) shale, (b) mudstone and (c) coal.

The instrument operated in a force-controlled mode had a loading and unloading rate of $60 \mathrm{mN} / \mathrm{min}$ [52] and a peak load of $30 \mathrm{mN}$. A load-depth curve also consists of a load-holding period of $5 \mathrm{~s}[53,54]$. Generally speaking, a great number of indents need to be created to calculate mechanical parameters due to the heterogeneous properties of coal and rock, but too many indents can influence microscale research efficiency and make experiments energy-consuming [51]. Therefore, the averaging method was used to calculate the mean values of hardness, elastic modulus, fracture toughness. If their average values were stable with the increase of experimental number, the number of experiments meet the requirement to calculate the mechanical parameters of coal and rock. 


\section{Results and Discussions}

\subsection{Load-Depth Curves}

The $F_{n}-h$ curves from the nanoindentation experiments under peak load of $30 \mathrm{mN}$ for shale, mudstone, and coal, are presented in Figure 5a-c, respectively.
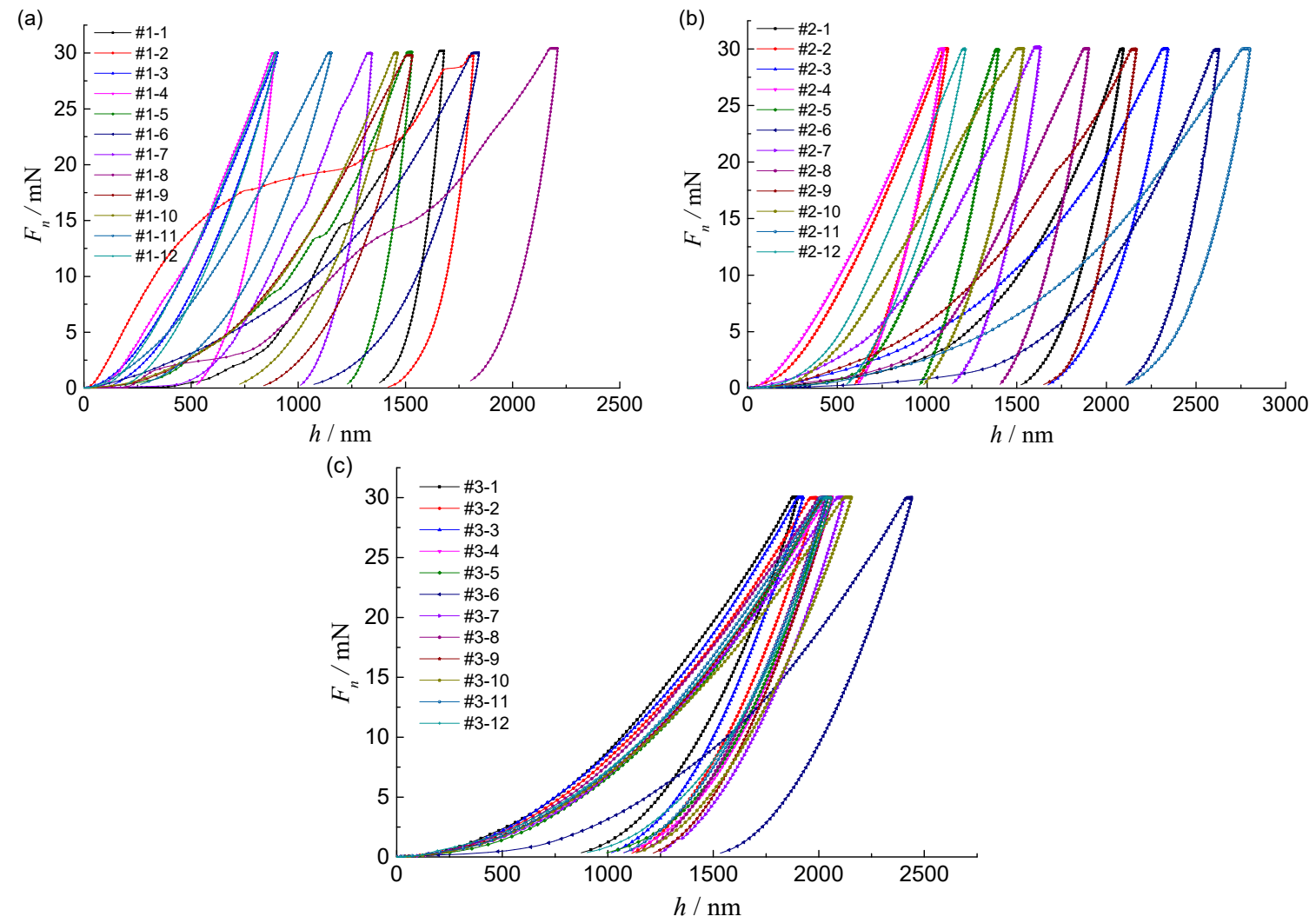

Figure 5. Load-depth curves of (a) shale, (b) mudstone and (c) coal.

It is obvious that different positions in a sample have various load-depth curves (Figure 6a), and the curves from different samples are likely to be similar (Figure 6b), which can be explained by the same mineral composite of shale, mudstone and coal.
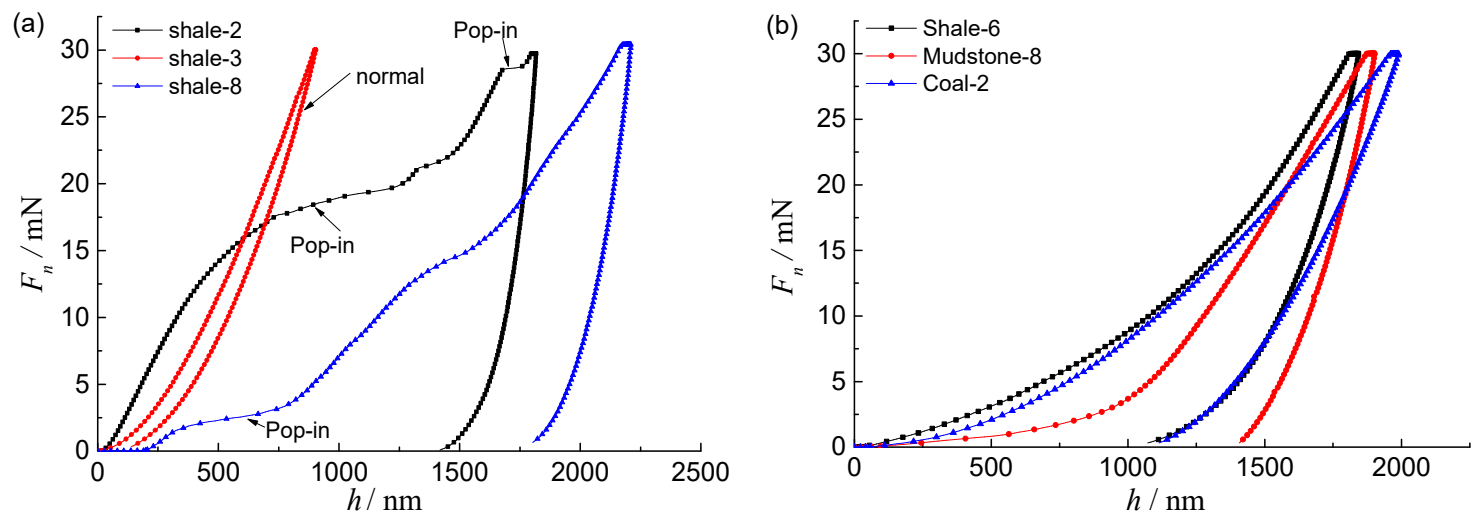

Figure 6. (a) Distinction and (b) similarity of load-depth curves.

According to Figures $6 \mathrm{a}$ and 7 , for shale-2, the slope of its load-depth curve is much larger than others at the first $500 \mathrm{~nm}$, so at this position it is a hard salient. However, the sudden decrease in 
slope for these lines, which also called pop-in, may be due to the formation of cracks or movement of particles around indenter. These abnormal phenomena would cause the inaccurate measurements of mechanical parameters of coal and rock if they are not removed. By contrast, when the indenter tip is located in a position with a pore or a crack, as in the curve of shale-8, it does not have load at the first $250 \mathrm{~nm}$ and has a very small slope at the first $750 \mathrm{~nm}$, which also influences the result accuracies.

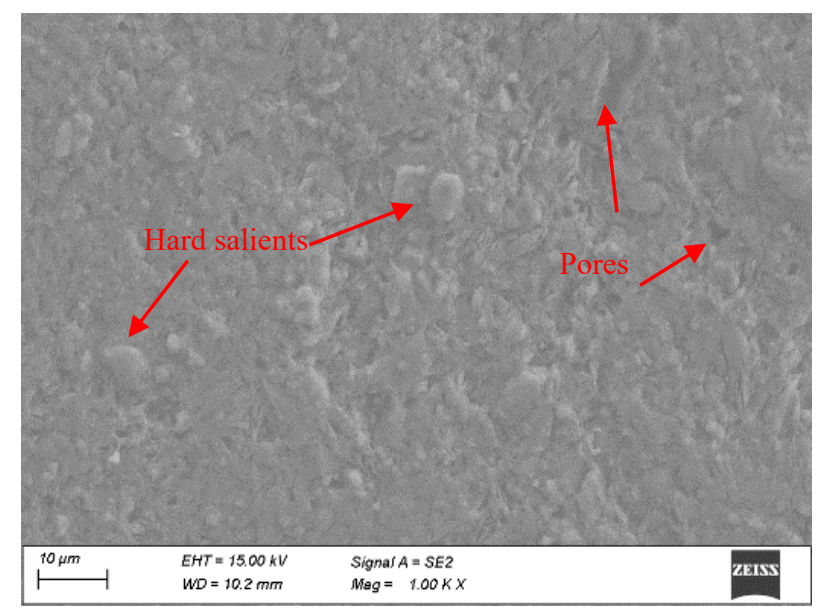

Figure 7. SEM image of shale showing hard salients and pores.

According to Figures $6 \mathrm{a}$ and 8 , if samples have the same mineral compositions, e.g., kaoline or quartz, their load-depth curves obtained in the microscale are likely to be similar. All those results show the heterogeneous properties of coal and rock due to the microstructures and mineral compositions at the microscale.
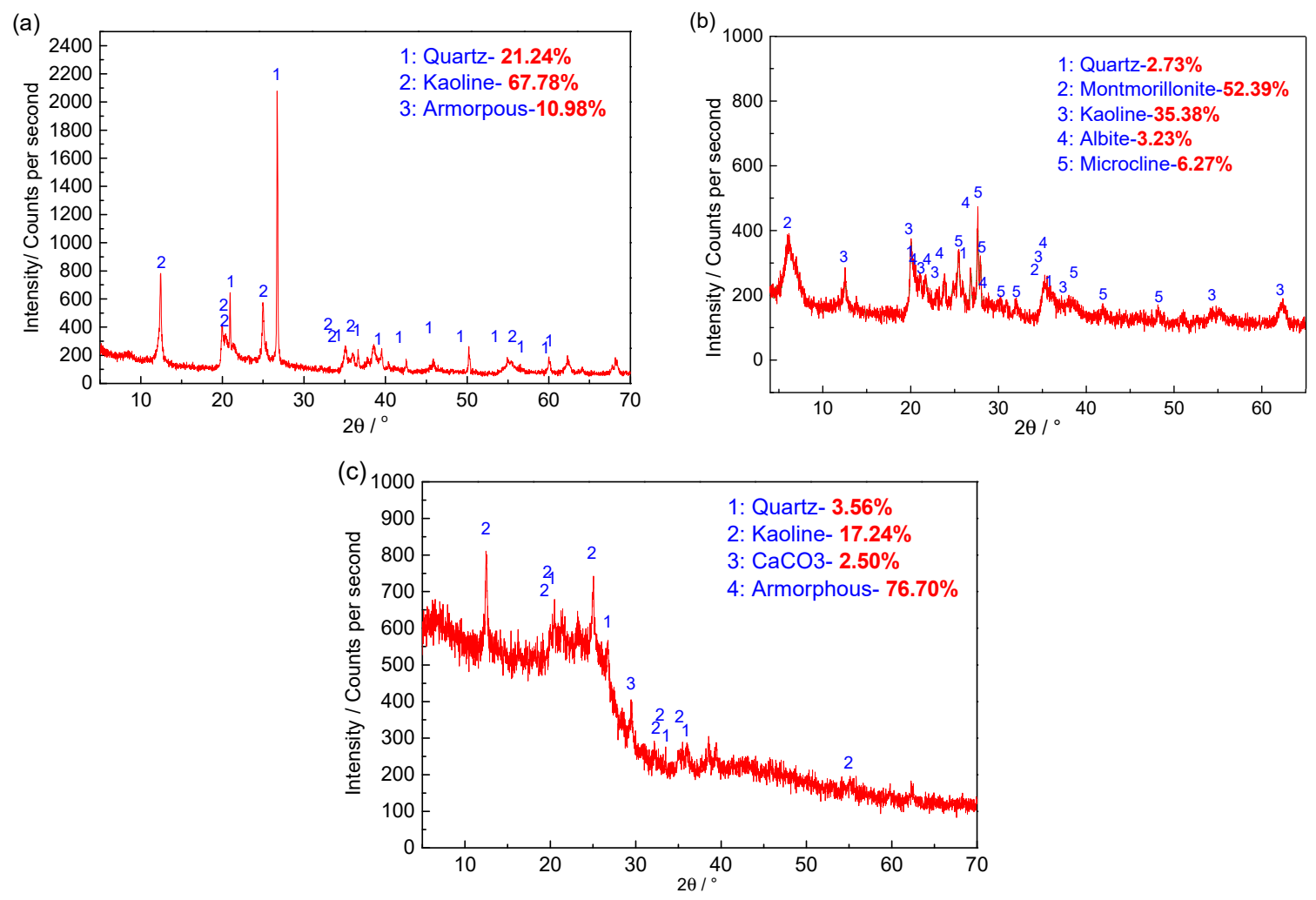

Figure 8. Mineral compositions of (a) shale, (b) mudstone and (c) coal. 


\subsection{Micromechanical Parameters}

Based on the load-depth curves in Figure 5, using the OP and fracture energy methods, the average values of the micromechanical parameters of shale, mudstone and coal are given by taking the number of experiments as the x-coordinate, as shown in Figure 9. It is clear that with the increase of experimental number, the average values of micromechanical parameters are becoming stable. When the number of experiments reaches 12 , micromechanical parameters can be used to represent the macromechanical parameters of coal and rock.
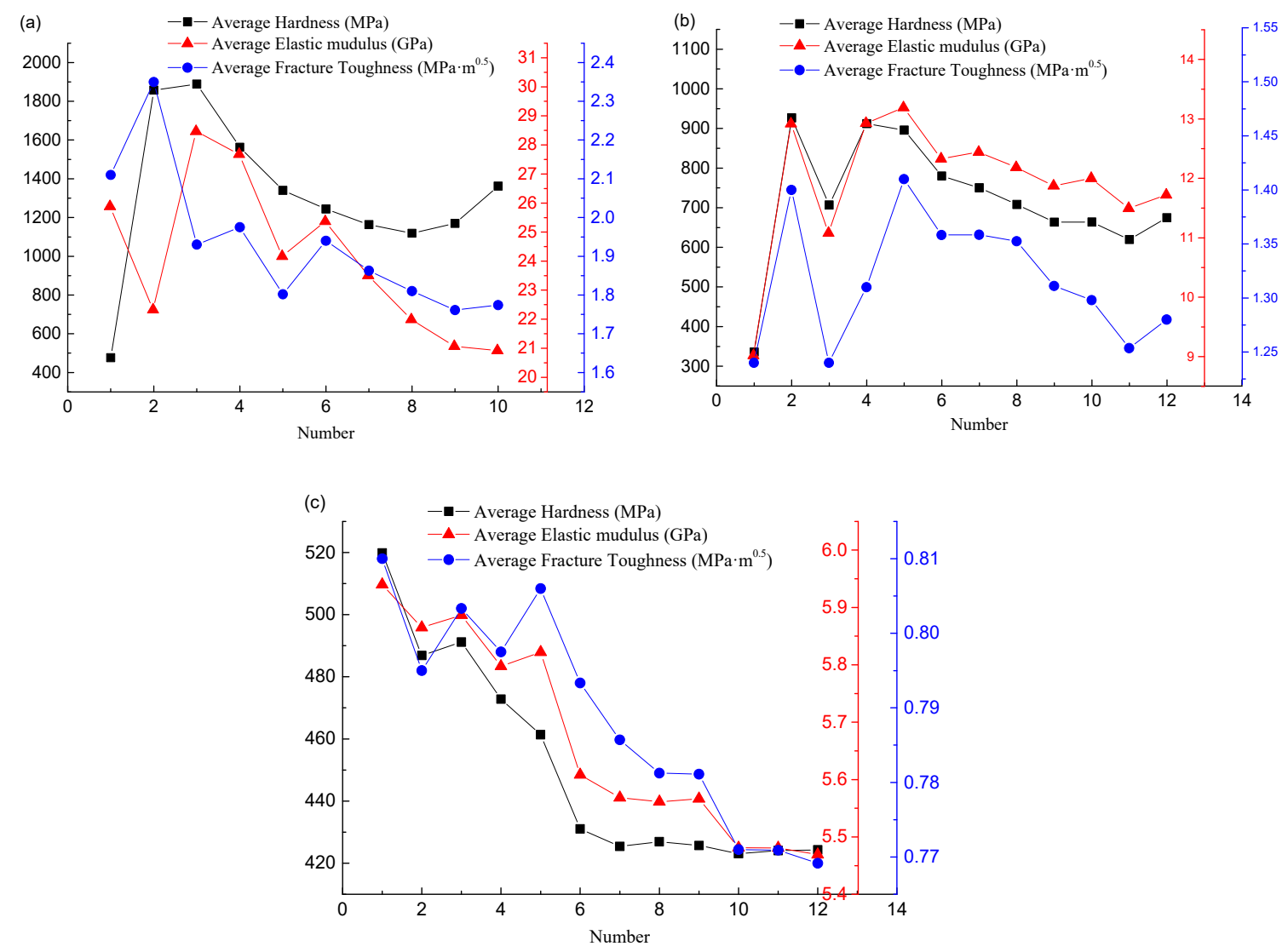

Figure 9. Relationship between the average values and experimental number of (a) shale, (b) mudstone and (c) coal.

Then, the hardness $\left(H_{I T}\right)$, elastic modulus $\left(E_{I T}\right)$, and fracture toughness $\left(K_{c}\right)$ of shale, mudstone, and coal were calculated and shown in Table 1.

For the mean values of hardness, elastic modulus, and fracture toughness, shale has the largest ones, which are $1191.90 \mathrm{MPa}, 20.39 \mathrm{GPa}$ and $1.66 \mathrm{MPa} \cdot \mathrm{m}^{0.5}$, respectively. It was followed by mudstone, with the values of $674.95 \mathrm{MPa}, 11.72 \mathrm{GPa}$ and $1.28 \mathrm{MPa} \cdot \mathrm{m}^{0.5}$. Coal is softer than mudstone in a near mine [55], and its mean values of micromechanical parameters were $424.30 \mathrm{MPa}, 5.47 \mathrm{GPa}$ and $0.77 \mathrm{MPa} \cdot \mathrm{m}^{0.5}$, respectively. 
Table 1. Micromechanical parameters of shale, mudstone, and coal.

\begin{tabular}{cccccccccc}
\hline \multirow{2}{*}{ No. } & \multicolumn{3}{c}{ Shale } & \multicolumn{3}{c}{ Mudstone } & \multicolumn{3}{c}{ Coal } \\
\cline { 2 - 11 } & $\boldsymbol{H}_{\boldsymbol{I T}}$ & $\boldsymbol{E}_{\boldsymbol{I T}}$ & $\boldsymbol{K}_{\boldsymbol{c}}$ & $\boldsymbol{H}_{\boldsymbol{I T}}$ & $\boldsymbol{E}_{\boldsymbol{I T}}$ & $\boldsymbol{K}_{\boldsymbol{c}}$ & $\boldsymbol{H}_{\boldsymbol{I T}}$ & $\boldsymbol{E}_{\boldsymbol{I T}}$ & $\boldsymbol{K}_{\boldsymbol{c}}$ \\
\hline 1 & 476.39 & 25.88 & 2.11 & 335.90 & 9.02 & 1.24 & 519.87 & 5.94 & 0.81 \\
2 & $/$ & $/$ & $/$ & 1517.50 & 16.82 & 1.56 & 453.89 & 5.79 & 0.78 \\
3 & 3238.90 & 18.78 & 2.59 & 267.10 & 7.40 & 0.92 & 499.76 & 5.93 & 0.82 \\
4 & 1951.30 & 40.74 & 1.09 & 1527.60 & 18.47 & 1.52 & 417.81 & 5.53 & 0.78 \\
5 & 585.23 & 25.31 & 2.11 & 830.67 & 14.25 & 1.81 & 415.51 & 5.92 & 0.84 \\
6 & 449.20 & 10.12 & 1.11 & 200.62 & 8.01 & 1.10 & 279.26 & 4.54 & 0.73 \\
7 & 761.73 & 31.37 & 2.63 & 573.31 & 13.12 & 1.36 & 391.74 & 5.33 & 0.74 \\
8 & $/$ & $/$ & $/$ & 412.69 & 10.39 & 1.31 & 437.66 & 5.51 & 0.75 \\
9 & 678.59 & 12.34 & 1.40 & 306.61 & 9.39 & 0.98 & 415.99 & 5.61 & 0.78 \\
10 & 809.27 & 11.36 & 1.44 & 664.65 & 13.13 & 1.18 & 399.25 & 4.71 & 0.68 \\
11 & 1580.60 & 13.74 & 1.37 & 179.39 & 6.46 & 0.81 & 434.08 & 5.48 & 0.77 \\
12 & 3089.20 & 19.58 & 1.89 & 1283.30 & 14.21 & 1.57 & 426.79 & 5.34 & 0.75 \\
Mean values & 1362.04 & 20.92 & 1.77 & 674.95 & 11.72 & 1.28 & 424.30 & 5.47 & 0.77 \\
\hline
\end{tabular}

\subsection{Heterogeneity of Coal and Rock}

\subsubsection{Profiles of Indents}

Figure 10 shows the profiles of indents on shale, mudstone and coal. Three pictures marked I are the profiles of indents according to the shape of indenter when depth is $h_{m}$. Pictures marked II are the profiles when depth is $h_{p}$ after unloading, which correspond to the pictures marked III obtained from the SEM. During the experiments, it was hard to obtain the SEM images of shale after indenting.

(a)

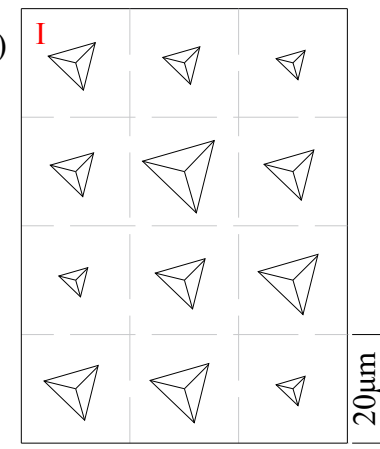

(b)

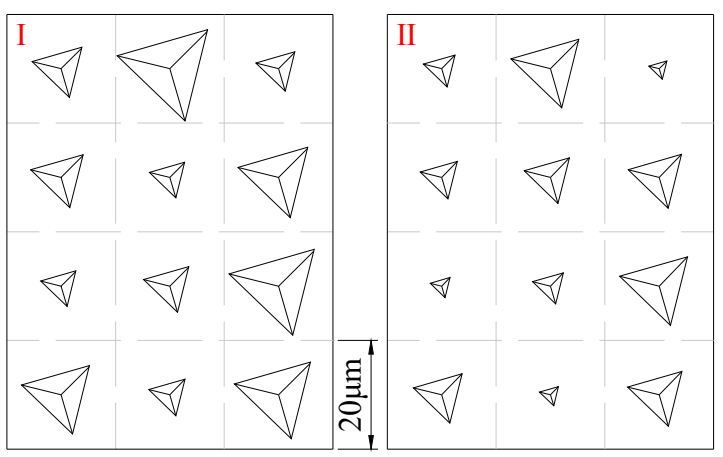

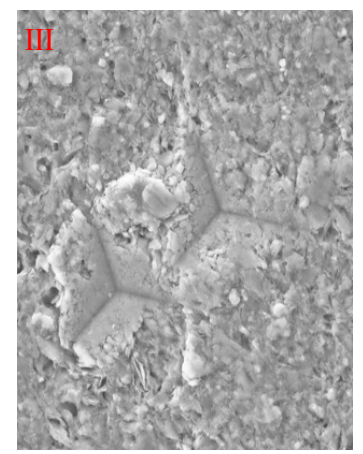

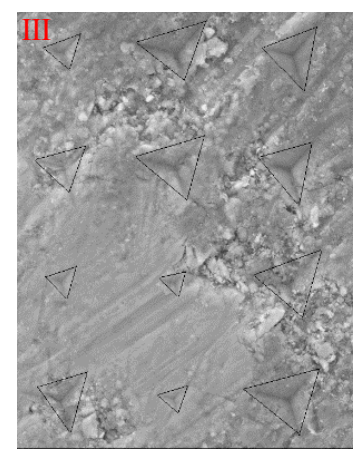

Figure 10. Cont. 
(c)

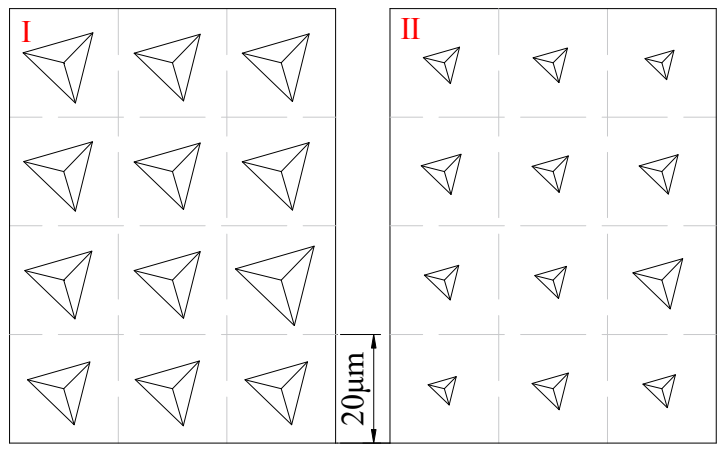

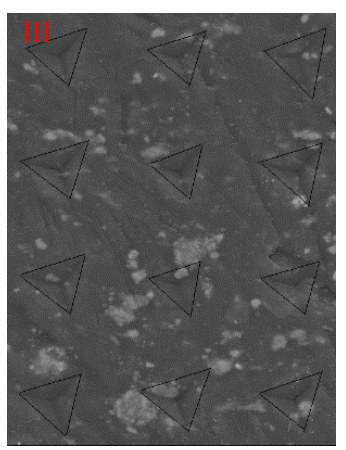

Figure 10. Profiles of indents of (a) shale, (b) mudstone and (c) coal.

According to Figure 10b, the indent of mudstone- 11 has the largest area. The depth during the load-holding is $2804.60 \mathrm{~nm}$, which is the largest depth, being $2112.47 \mathrm{~nm}$ after unloading. In contrast, testing shale-3 has the smallest indention area, with the maximum loading depth of $905.99 \mathrm{~nm}$ and unloading depth of $139.09 \mathrm{~nm}$.

Mainly based on picture I in Figure 10a-c, the differences between the no.1 to 12 indents on the surface of shale are greater than the other two samples, which means the heterogeneous properties of shale are more differentiated than mudstone and coal. It is noticeable, however, that the indent areas obtained from the SEM (picture III) are much larger than that got from calculation (picture II). During unloading, elastic recovery causes these impressions to change their initial shape [56]. This phenomenon illustrates that the elastic recovery of the impression is not equal for the whole area, and the tip of indenter is the largest recovery position (Figure 3b), meaning that the stress under an indent varies from high levels in the vicinity of the tip, to vanishingly small values far away from it [57]. Figure 10a-III, b-III, and c-III show no obvious pile-up on the surfaces of rock and coal around the contact impression, even though they are elastic-plastic materials, which guarantees the measurement accuracy of micro hardness, elastic modulus, and fracture toughness [58].

\subsubsection{Statistical Analysis of Micromechanical Parameters}

In this study, the heterogeneities of coal and rock are not only limited to the mineral compositions and the microstructure, but also comprise the micromechanical parameters obtained from nanoindentation tests. As a result, the heterogeneities of coal and rock can be quantified and mapped using the micromechanical parameters. Figure 11 shows the results of statistical analysis of micromechanical parameters.
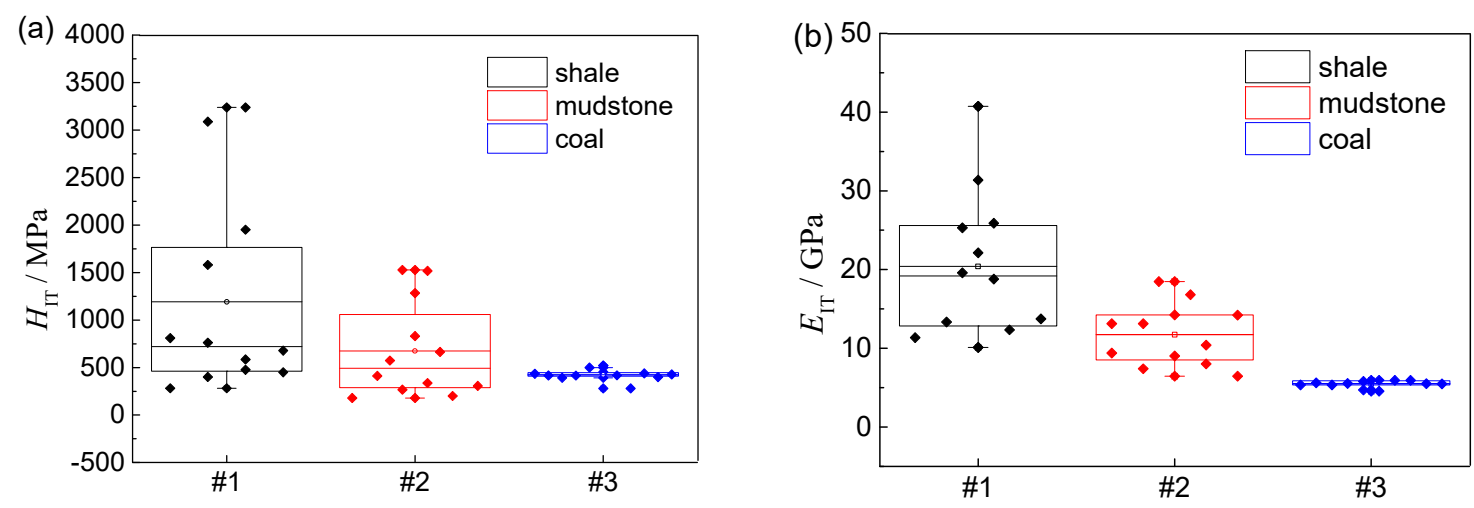

Figure 11. Cont. 


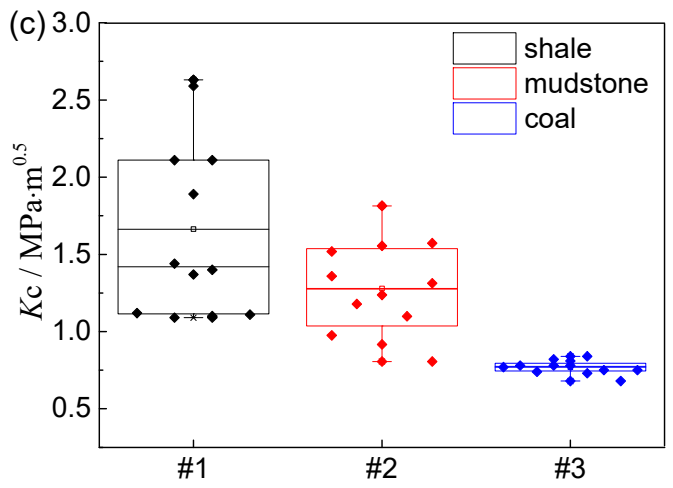

Figure 11. Statistical analyses of (a) hardness, (b) elastic modulus and (c) fracture toughness.

According to the data in Figure 11, the heterogeneous properties of coal and rock were initially quantified based on the micromechanical properties. For example, the IQR of the hardness of shale, mudstone, and coal is $1502.10 \mathrm{MPa}, 1016.20 \mathrm{MPa}, 54.64 \mathrm{MPa}$, respectively. The IQR of other parameters are also illustrated in Figure 11. This coal sample has a better homogeneity than other two samples.

\subsubsection{Heterogeneous Properties Maps}

Zhang et al. only drew the indentation moduli maps of sub-bituminous coal in microscale [46] and Liu also provided the creep displacement of shale [51]. Even though these researchers investigated larger areas, about $300 \times 300 \mu \mathrm{m}$, they just focused on one parameter. Based on the profiles of indents in Figure 10 and Table 1, in the micro-area of $60 \times 80 \mu \mathrm{m}$, the heterogeneous properties of the three samples are shown in Figure 12 including hardness, elastic modulus and fracture toughness.
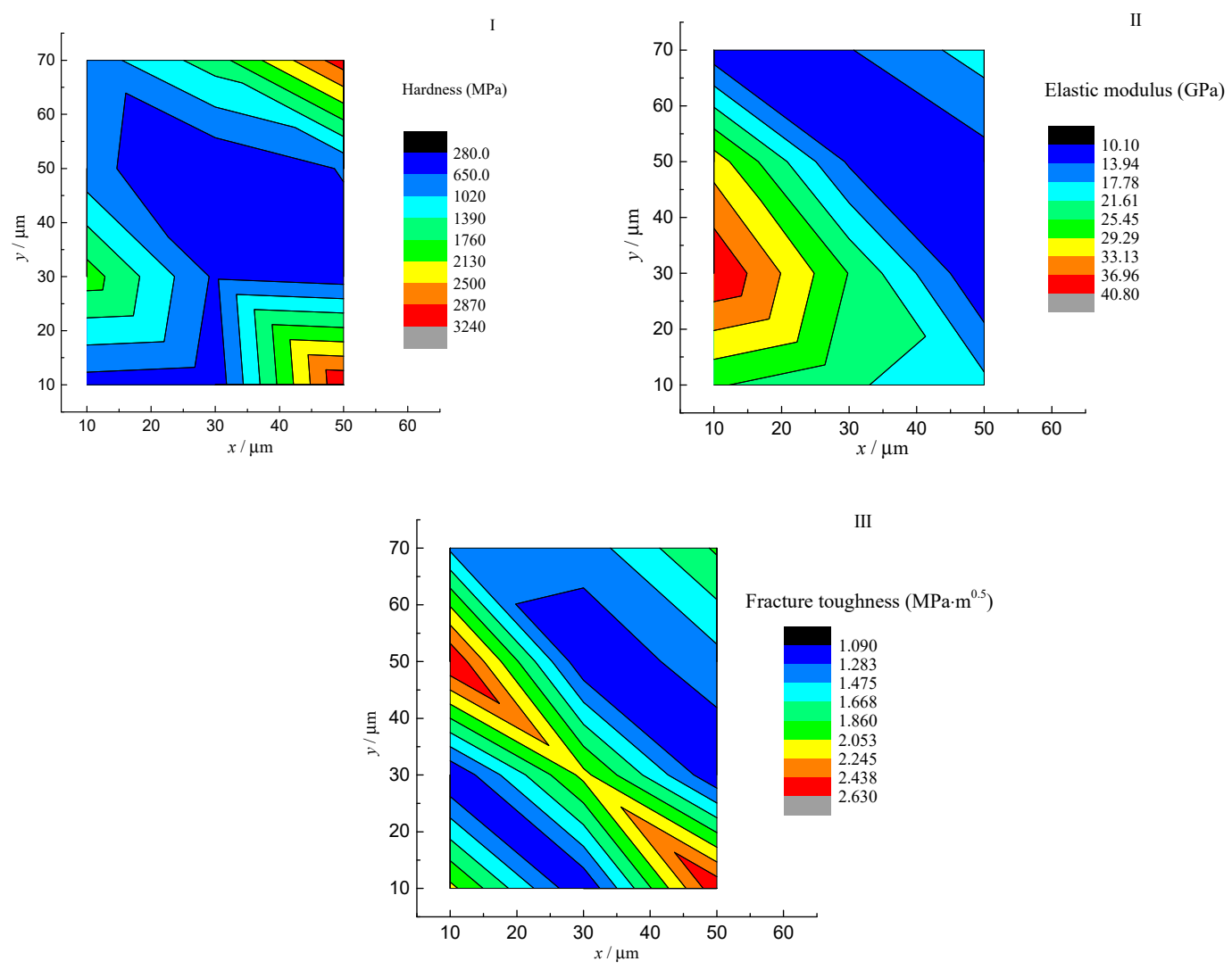

(a) Shale

Figure 12. Cont. 

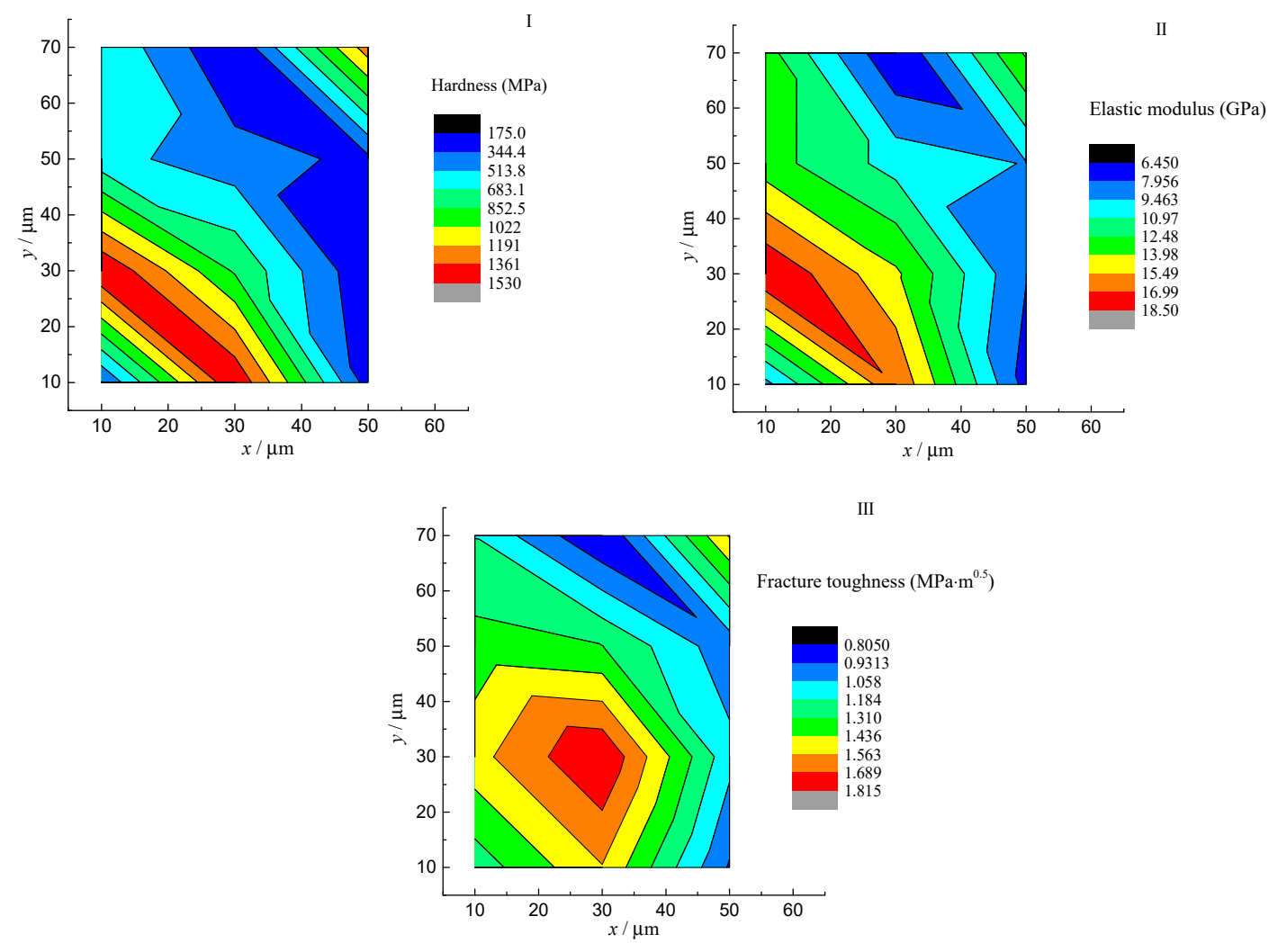

(b) Mudstone
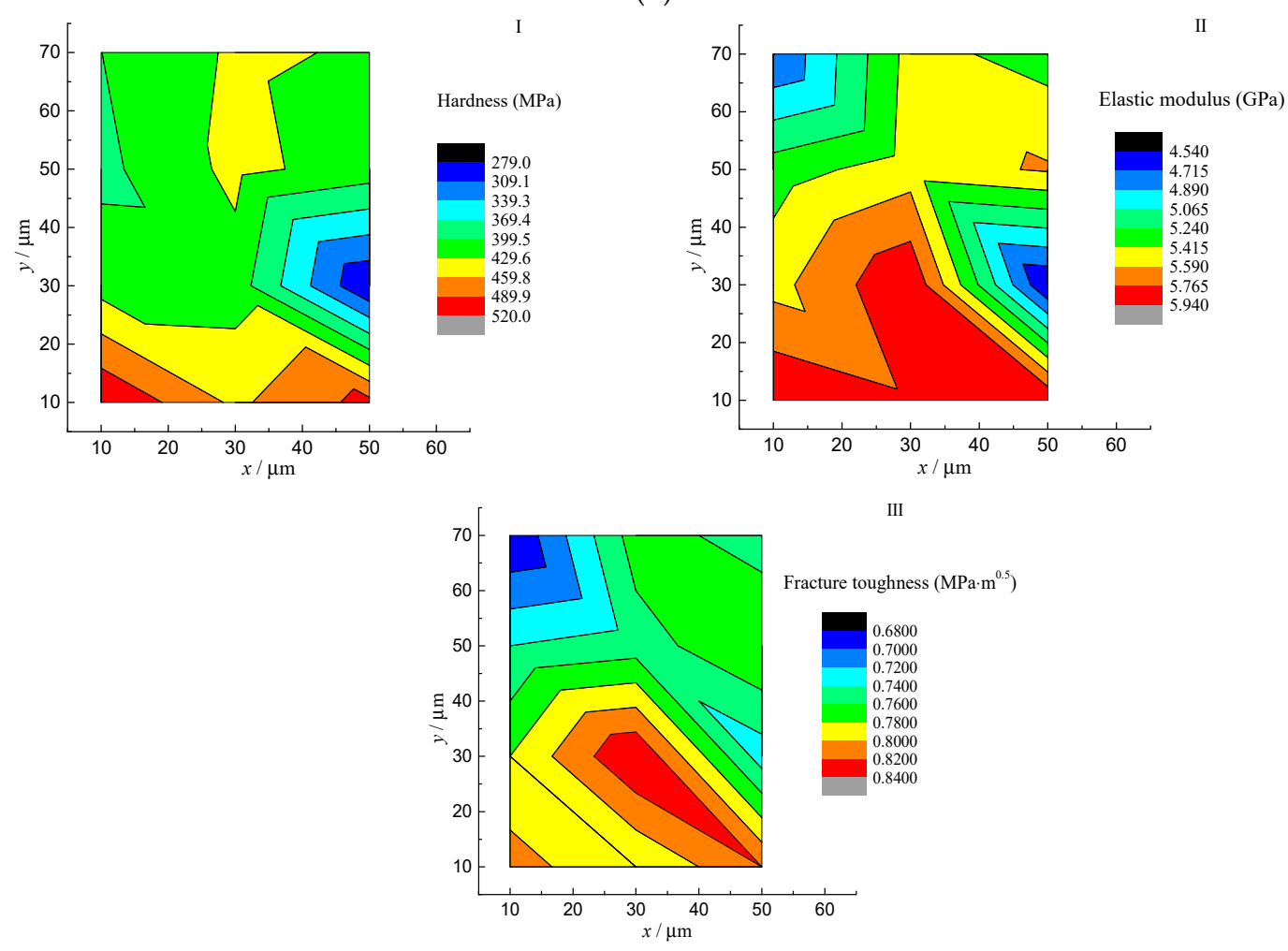

(c) Coal

Figure 12. Heterogeneity maps of (a) shale (b) mudstone and (c) coal. 
In Figure 12, maps labelled I, II, III are hardness, elastic modulus and fracture toughness, respectively. It can be seen that different locations possess different micromechanical parameters. Even though some researchers thought these differences are due to the heterogeneous nature which originates from various phases that exist in coal and rock [51,59], this research showed that the microstructures of samples also play an important role to determine the differences of the maps of micromechanical parameters, which are avoided as possible in this study. It's worth noting that the distributions of different micromechanical parameters for one sample are very similar. For example, in Figure 12a, the position of $(40,50)$ has a lowest hardness, elastic moduli and fracture toughness.

\section{Conclusions}

To investigate the mechanical properties of soft and broken coal and rock obtained from coal mines, nanoindentation was used in this study.

Grid nanoindentation and averaging method were adopted to obtain the micromechanics of shale, mudstone, and coal. Based on the OP and fracture energy methods, the mean hardness of shale, mudstone, coal are $1191.90 \mathrm{MPa}, 674.95 \mathrm{MPa}$ and $424.30 \mathrm{MPa}$, respectively; their mean elastic moduli are 20.39 GPa, 11.72 GPa and 5.47 GPa; and their mean fracture toughness were $1.66 \mathrm{~Pa} \cdot \mathrm{m}^{0.5}, 1.28 \mathrm{~Pa} \cdot \mathrm{m}^{0.5}$ and $0.77 \mathrm{~Pa} \cdot \mathrm{m}^{0.5}$. So, among them, the strength of shale is the largest, which is followed by mudstone, and coal is the weakest. This is consistent with our general understanding and previous studies.

The heterogeneous properties of coal and rock can be explained through above three mechanical parameters, which is a comprehensive indicator, and reflect the influence of mineral compositions and microstructure. According to it, the IQR of hardness of shale, mudstone and coal are 1502.10 MPa, 1016.20 MPa and 54.64 MPa, meaning that coal has the largest heterogeneity among them. Since coal and rock have different mineral compositions and microstructures, they have various micromechanical parameters.

This study not only uses and verifies a method to calculate the mechanical parameters of soft and broken coal and rock, but also proves that they are typical heterogeneous materials and that it is incorrect to regard them as homogeneous body. Future research hotspot will be on the implementation of those mechanical parameters.

Author Contributions: C.S., G.L. conceived and designed the experiments; C.S., S.Z. and J.X. performed the experiments and analyzed the data; C.S., G.L. and H.Y. wrote the paper. All authors have read and agreed to the published version of the manuscript.

Funding: The work presented in this paper was supported by the projects of the "National Key Research and Development Program (2016YFC0600901)" and the "National Natural Science Foundation of China (No. 51574224)".

Acknowledgments: The authors are grateful to the anonymous reviewers for carefully reading the manuscript and providing many helpful comments to improve the quality of this work. Besides, Changlun Sun acknowledges, in particular, the powerful support received from his girlfriend, Fan Zhou, over the years.

Conflicts of Interest: The authors declare no conflict of interest.

\section{References}

1. He, M.; Ren, F.; Cheng, C. Experimental and numerical analyses on the effect of stiffness on bedded sandstone strain burst with varying dip angle. Bull. Eng. Geol. Environ. 2018, 78, 3593-3610. [CrossRef]

2. Hu, J.; He, M.; Wang, J.; Ma, Z.; Wang, Y.; Zhang, X. Key Parameters of Roof Cutting of Gob-Side Entry Retaining in a Deep Inclined Thick Coal Seam with Hard Roof. Energies 2019, 12, 934. [CrossRef]

3. Wang, Q.; He, M.; Yang, J.; Gao, H.; Jiang, B.; Yu, H. Study of a no-pillar mining technique with automatically formed gob-side entry retaining for longwall mining in coal mines. Int. J. Rock Mech. Min. Sci. 2018, 110, 1-8. [CrossRef]

4. Kang, H.; Lou, J.; Gao, F.; Yang, J.; Li, J. A physical and numerical investigation of sudden massive roof collapse during longwall coal retreat mining. Int. J. Coal Geol. 2018, 188, 25-36. [CrossRef]

5. Gao, F.; Kang, H. Experimental Study on the Residual Strength of Coal Under Low Confinement. Rock Mech. Rock Eng. 2016, 50, 285-296. [CrossRef] 
6. Kang, H.; Li, J.; Yang, J.; Gao, F. Investigation on the Influence of Abutment Pressure on the Stability of Rock Bolt Reinforced Roof Strata Through Physical and Numerical Modeling. Rock Mech. Rock Eng. 2016, 50, 387-401. [CrossRef]

7. Huang, B.; Cheng, Q.; Zhao, X.; Kang, C. Hydraulic fracturing of hard top coal and roof for controlling gas during the initial mining stages in longwall top coal caving: A case study. J. Geophys. Eng. 2018, 15, 2492-2506. [CrossRef]

8. Huang, B.; Liu, J.; Zhang, Q. The reasonable breaking location of overhanging hard roof for directional hydraulic fracturing to control strong strata behaviors of gob-side entry. Int. J. Rock Mech. Min. 2018, 103, 1-11. [CrossRef]

9. Kang, H.; Lv, H.; Gao, F.; Meng, X.; Feng, Y. Understanding mechanisms of destressing mining-induced stresses using hydraulic fracturing. Int. J. Coal Geol. 2018, 196, 19-28. [CrossRef]

10. Cao, A.; Dou, L.; Cai, W.; Gong, S.; Liu, S.; Jing, G. Case study of seismic hazard assessment in underground coal mining using passive tomography. Int. J. Rock Mech. Min. 2015, 78, 1-9. [CrossRef]

11. He, J.; Dou, L.; Gong, S.; Li, J.; Ma, Z. Rock burst assessment and prediction by dynamic and static stress analysis based on micro-seismic monitoring. Int. J. Rock Mech. Min. 2017, 93, 46-53. [CrossRef]

12. Wang, H.; Zhang, B.; Yuan, L.; Yu, G.; Wang, W. Gas Release Characteristics in Coal under Different Stresses and Their Impact on Outbursts. Energies 2018, 11, 2661. [CrossRef]

13. Wu, Q.; Zhao, D.; Wang, Y.; Shen, J.; Mu, W.; Liu, H. Method for assessing coal-floor water-inrush risk based on the variable-weight model and unascertained measure theory. Hydrogeol. J. 2017, 25, 2089-2103. [CrossRef]

14. Wu, Q.; Mu, W.; Xing, Y.; Qian, C.; Shen, J.; Wang, Y.; Zhao, D. Source discrimination of mine water inrush using multiple methods: A case study from the Beiyangzhuang Mine, Northern China. Bull. Eng. Geol. Environ. 2017, 78, 469-482. [CrossRef]

15. Liu, Z.B.; Xie, S.Y.; Shao, J.F.; Conil, N. Effects of deviatoric stress and structural anisotropy on compressive creep behavior of a clayey rock. Appl. Clay Sci. 2015, 114, 491-496. [CrossRef]

16. Armand, G.; Conil, N.; Talandier, J.; Seyedi, D.M. Fundamental aspects of the hydromechanical behaviour of Callovo-Oxfordian claystone: From experimental studies to model calibration and validation. Comput. Geotech. 2017, 85, 277-286. [CrossRef]

17. Shahbazi, M.; Najafi, M.; Marji, M.F. On the mitigating environmental aspects of a vertical well in underground coal gasification method. Mitig. Adapt. Strateg. Glob. Chang. 2018, 24, 373-398. [CrossRef]

18. Zhang, S.; Wu, S.; Chu, C.; Guo, P.; Zhang, G. Acoustic Emission Associated with Self-Sustaining Failure in Low-Porosity Sandstone Under Uniaxial Compression. Rock Mech. Rock Eng. 2018, 52, 2067-2085. [CrossRef]

19. Li, W.; Jin, Z.; Cusatis, G. Size Effect Analysis for the Characterization of Marcellus Shale Quasi-brittle Fracture Properties. Rock Mech. Rock Eng. 2018, 52, 1-18. [CrossRef]

20. Zhou, X.-P.; Wang, Y.-T.; Zhang, J.-Z.; Liu, F.-N. Fracturing Behavior Study of Three-Flawed Specimens by Uniaxial Compression and 3D Digital Image Correlation: Sensitivity to Brittleness. Rock Mech. Rock Eng. 2018, 52, 691-718. [CrossRef]

21. Mehranpour, M.H.; Kulatilake, P.H.S.W.; Ma, X.G.; He, M.C. Development of New Three-Dimensional Rock Mass Strength Criteria. Rock Mech. Rock Eng. 2018, 51, 3537-3561. [CrossRef]

22. Feng, X.-T.; Kong, R.; Zhang, X.; Yang, C. Experimental Study of Failure Differences in Hard Rock under True Triaxial Compression. Rock Mech. Rock Eng. 2019, 52, 2109-2122. [CrossRef]

23. Sun, C.; Li, G.; Sun, Y.; He, J.; Rong, H. Modelling Hydration Swelling and Weakening of Montmorillonite Particles in Mudstone. Processes 2019, 7, 428. [CrossRef]

24. Kalei, G.N. Some results of microhardness test using the depth of impression. Mashinovedenie 1968, 4, 105-107.

25. Borodich, F.M. The Hertz-Type and Adhesive Contact Problems for Depth-Sensing Indentation. Adv. Appl. Mech. 2014, 47, 225-366.

26. Doerner, M.F.; Nix, W.D. A method for interpreting the data from depth-sensing indentation instruments. J. Mater. Res. 2011, 1, 601-609. [CrossRef]

27. Oliver, W.C.; Pharr, G.M. An improved technique for determining hardness and elastic modulus using load and displacement sensing indentation experiments. J. Mater. Res. 1992, 7, 1564-1583. [CrossRef]

28. Oliver, W.C.; Pharr, G.M. Measurement of hardness and elastic modulus by instrumented indentation: Advances in understanding and refinements to methodology. J. Mater. Res. 2004, 19, 3-20. [CrossRef] 
29. Chen, J.; Bull, S.J. Indentation fracture and toughness assessment for thin optical coatings on glass. J. Phys. D Appl. Phys. 2007, 40, 5401-5417. [CrossRef]

30. Li, X.D.; Bhushan, B. Evaluation of fracture toughness of ultra-thin amorphous carbon coatings deposited by different deposition techniques. Thin Solid Film. 1999, 355, 330-336. [CrossRef]

31. Beake, B.D.; Goodes, S.R.; Smith, J.F. Micro-Impact Testing: A New Technique for Investigating Thin Film Toughness, Adhesion, Erosive Wear Resistance, and Dynamic Hardness. Surf. Eng. 2013, 17, 187-192. [CrossRef]

32. Naderi, S.; Dabbagh, A.; Hassan, M.A.; Razak, B.A.; Abdullah, H.; Abu Kasim, N.H. Modeling of porosity in hydroxyapatite for finite element simulation of nanoindentation test. Ceram. Int. 2016, 42, 7543-7550. [CrossRef]

33. Tanguy, M.; Bourmaud, A.; Baley, C. Plant cell walls to reinforce composite materials: Relationship between nanoindentation and tensile modulus. Mater. Lett. 2016, 167, 161-164. [CrossRef]

34. Xiao, G.; Yang, X.; Yuan, G.; Li, Z.; Shu, X. Mechanical properties of intermetallic compounds at the $\mathrm{Sn}-3.0 \mathrm{Ag}-0.5 \mathrm{Cu} / \mathrm{Cu}$ joint interface using nanoindentation. Mater. Des. 2015, 88, 520-527. [CrossRef]

35. Zhang, C.Y.; Guo, B.; Zhao, Q.L.; Liu, H.; Wang, J.H.; Zhang, J. Ultra-precision grinding of AlON ceramics: Surface finish and mechanisms. J. Eur. Ceram. Soc. 2019, 39, 3668-3676. [CrossRef]

36. Qu, Z.H.; Meredith, J.C. The atypically high modulus of pollen exine. J. R. Soc. Interface 2018, 15. [CrossRef]

37. Zhu, W.; Hughes, J.J.; Bicanic, N.; Pearce, C.J. Nanoindentation mapping of mechanical properties of cement paste and natural rocks. Mater. Charact. 2007, 58, 1189-1198. [CrossRef]

38. Alstadt, K.N.; Katti, K.S.; Katti, D.R. Nanoscale Morphology of Kerogen and In Situ Nanomechanical Properties of Green River Oil Shale. J. Nanomech. Micromech. 2016, 6. [CrossRef]

39. Mashhadian, M.; Verde, A.; Sharma, P.; Abedi, S. Assessing mechanical properties of organic matter in shales: Results from coupled nanoindentation/SEM-EDX and micromechanical modeling. J. Pet. Sci. Eng. 2018, 165, 313-324. [CrossRef]

40. Abedi, S.; Slim, M.; Hofmann, R.; Bryndzia, T.; Ulm, F.-J. Nanochemo-mechanical signature of organic-rich shales: A coupled indentation-EDX analysis. Acta Geotech. 2016, 11, 559-572. [CrossRef]

41. Bobko, C.P. Assessing the Mechanical Microstructure of Shale by Nanoindentation-The Link between Mineral Composition and Mechanical Properties. Ph.D. Thesis, Massachustts Institute of Technology, Cambridge, MA, USA, 2008.

42. Bobko, C.; Ulm, F.-J. The nano-mechanical morphology of shale. Mech. Mater. 2008, 40, 318-337. [CrossRef]

43. Delafargue, A. Material Invariant Properties of Shales: Nanoindentation and Microporoelastic Analysis. Master's Thesis, Massachustts Institute of Technology, Cambridge, MA, USA, 2003.

44. Gathier, B. Multiscale Strength Homogenization-Application to Shale Nanoindentation. Master's Thesis, Massachustts Institute of Technology, Cambridge, MA, USA, 2006.

45. Kossovich, E.L.; Borodich, F.M.; Epshtein, S.A.; Galanov, B.A.; Minin, M.G.; Prosina, V.A. Mechanical, structural and scaling properties of coals: Depth-sensing indentation studies. Appl. Phys. A 2019, 125, 195. [CrossRef]

46. Zhang, Y.; Lebedev, M.; Al-Yaseri, A.; Yu, H.; Xu, X.; Iglauer, S. Characterization of nanoscale rockmechanical properties and microstructures of a Chinese sub-bituminous coal. J. Nat. Gas Sci. Eng. 2018, 52, 106-116. [CrossRef]

47. Stillwell, N.A.; Tabor, D. Elastic recovery of conical indentations. Proc. Phys. Soc. 1961, 78, 169. [CrossRef]

48. King, R.B. Elastic analysis of some punch problems for a layered medium. Int. J. Solids Struct. 1987, 23, 1657-1664. [CrossRef]

49. Sneddon, I.N. The relation between load and penetration in the axisymmetric boussinesq problem for a punch of arbitrary profile. Int. J. Eng. Sci. 1965, 3, 47-57. [CrossRef]

50. Liu, K.; Ostadhassan, M.; Bubach, B. Applications of nano-indentation methods to estimate nanoscale mechanical properties of shale reservoir rocks. J. Nat. Gas Sci. Eng. 2016, 35, 1310-1319. [CrossRef]

51. Liu, K.; Ostadhassan, M.; Bubach, B. Application of nanoindentation to characterize creep behavior of oil shales. J. Pet. Sci. Eng. 2018, 167, 729-736. [CrossRef]

52. Bennett, K.C.; Berla, L.A.; Nix, W.D.; Borja, R.I. Instrumented nanoindentation and 3D mechanistic modeling of a shale at multiple scales. Acta Geotech. 2015, 10,1-14. [CrossRef]

53. Constantinides, G.; Ulm, F.-J. The nanogranular nature of C-S-H. J. Mech. Phys. Solids 2007, 55, 64-90. [CrossRef] 
54. Miller, M.; Bobko, C.; Vandamme, M.; Ulm, F.J. Surface roughness criteria for cement paste nanoindentation. Cem. Concr. Res. 2008, 38, 467-476. [CrossRef]

55. Basarir, H.; Sun, Y.; Li, G. Gateway stability analysis by global-local modeling approach. Int. J. Rock Mech. Min. 2019, 113, 31-40. [CrossRef]

56. Pharr, G.M.; Bolshakov, A. Understanding nanoindentation unloading curves. J. Mater. Res. 2011, 17, 2660-2671. [CrossRef]

57. Goodall, R.; Clyne, T.W. A critical appraisal of the extraction of creep parameters from nanoindentation data obtained at room temperature. Acta Mater. 2006, 54, 5489-5499. [CrossRef]

58. Bolshakov, A.; Pharr, G.M. Influences of pileup on the measurement of mechanical properties by load and depth sensing indentation techniques. J. Mater. Res. 2011, 13, 1049-1058. [CrossRef]

59. Liu, K.; Ostadhassan, M.; Bubach, B.; Ling, K.; Tokhmechi, B.; Robert, D. Statistical grid nanoindentation analysis to estimate macro-mechanical properties of the Bakken Shale. J. Nat. Gas Sci. Eng. 2018, 53, 181-190. [CrossRef]

(C) 2020 by the authors. Licensee MDPI, Basel, Switzerland. This article is an open access article distributed under the terms and conditions of the Creative Commons Attribution (CC BY) license (http://creativecommons.org/licenses/by/4.0/). 